Varieties of CSR: Institutions and Socially Responsible Behaviour

\author{
Professor Mehmet Demirbag* \\ University of Essex, Essex Business School \\ Elmer Approach, Southend on Sea \\ SS1 1LW \\ United Kingdom \\ Tel: +44 1702328200 \\ E-mail: $\underline{\text { mdemirc@essex.ac.uk }}$ \\ Professor Geoffrey Wood \\ University of Essex, Essex Business School \\ Wivenhoe Park, Colchester \\ C04 3SQ \\ United Kingdom \\ Tel: +44 1206872375 \\ E-mail: gtwood@essex.ac.uk \\ Dr Dilshod Makhmadshoev \\ University of Strathclyde, Strathclyde Business School \\ 199 Cathedral Street \\ Glasgow \\ Tel: +44 1415536010 \\ E-mail: dilshod.makhmadshoev@strath.ac.uk
}

Dr Olga Rymkevich

University of Modena and Reggio Emilia

Italy

Tel: +39 (059)2056042

E-mail: rymkevich@unimore.it

*Corresponding author 
Varieties of CSR: Institutions and Socially Responsible Behaviour

\begin{abstract}
A central concern within contemporary socio-economics has been on the relationship between national institutional configurations and societal outcomes. In this paper, we assess the relationship between legal origin and a range of correlated indicators of social responsibility, focusing on socially responsible investing and voluntary charitable giving. We found that in Common Law contexts, lower levels of social responsibility than in Civil Law contexts, other than in the area of charitable giving, where the converse was the case. We explore the reasons for this distinction, and for the different patterns encountered in post-socialist Central and Eastern Europe. Based on the findings, we identify directions for future research.
\end{abstract}

Keywords: Legal origin; corporate social responsibility; socially responsible investing; charitable giving; comparative institutional analysis. 


\section{Legal Origin and Corporate Social Responsibility around the World}

\section{Introduction}

This is a study on the relationship between legal origin and Corporate Social Responsibility (CSR). We supplement this with an analysis of the effects of corruption on voluntary giving. Legal origin is defined according to the widely deployed categories of La Porta et al. (2008), which divides countries into legal families, according to whether corporate law is primarily the result of legislation or judicial decisions. Meanwhile, voluntary CSR and country giving rates are derived from the Global Competitiveness Report (Porter et al, 2004; 2005) and the World Giving Index (CAF, 2010) respectively, and corruption from the World Bank Worldwide Governance index (2010). A central theme in the existing academic literature has been the relationship between institutions, and the relative resource allocations and power accorded to different players. There are relatively few studies on the relationship between institutional context and corporate social responsibility practices (Brammer et al., 2012). This study adds to the literature through bringing new data to the table, and focusing on a wide range of countries, and confirms the persistence of national difference, with CSR being more widespread in civil law countries.

It has been argued that corporations are experiencing increased pressures to align their business with ethical norms and practices, balancing CSR practices with business and ethical norms and values (Jawahar and McLaughlin, 2001). Yet, there are many different indices of corporate social responsibility that aim to intermesh economic and ethical principles in the context of wider business decisions (Brown and Forster, 2013; Gjølberg 2009). CSR practices can be broadly distinguished along the economic, ethical, and environmental dimensions (Carroll, 1991; Schwartz and Carroll, 2003). The former includes not only codes of conduct/corruption, risk and crisis management, and customer and investment relations (Jackson and Apostolakou 2010), but also overall patterns of investment (Bengtsson 2008). The ethical dimensions of CSR range from labour practices to social reporting, and environmental from energy efficiency to environmental marketing. 
While there is no scarcity of discussions regarding the social and ethical roots of CSR and its implication for the performance of companies (Brown and Forster, 2013; Kiessling et al, 2015), only a limited amount of comparative work linking CSR to institutional settings exists (Tatoglu et al., 2014; Brammer et. al. 2012; Campbell, 2007), deploying one or other of the capitalist archetypes identified within the literature on comparative capitalism (Jackson and Apostolakou 2010, p.371; Jamali et al, 2009; Matten and Moon 2008). A central theme in the literature has been seeking to focus on differences between mature economies where shareholder rights are paramount (developed Common Law/Liberal Market Economies [LMEs]), and those where shareholder rights are weaker and those of other stakeholders stronger (developed Civil Law/Coordinated Market Economies [CMEs]). In contrast to the Varieties of Capitalism and similar approaches to comparative capitalism, legal origin theory has limitations in that it accords primacy to a single institutional characteristic. However, the national categories that form the centre of such analysis (civil vs common law) can be applied to all economies, whether developed or not.

The vast majority of comparative CSR research has been conducted in developed economies, while insights from developing, mixed and 'transitional' post-socialist countries have been scant (Jamali and Mirshak, 2007; Tatoglu et al., 2014). This paper aims to contribute to this lacuna by exploring (Matten and Moon 2008) the effect of legal origin on two distinct areas that have been widely considered as key features of CSR: socially responsible investing (SRI) and charitable giving (Hill et. al, 2007; Jamali and Mirshak, 2007).

A common feature of both the Legal Origin approach and the classic literature on comparative capitalism is that there is a focus on institutional feature and societal level outcomes (Hall and Soskice 2001; La Porta et al. 2008; Wood et al. 2014); actors respond to embedded societal structures and associated relations to generate broad patterns of economic growth and variations in relative stakeholder prosperity. Such analysis is firm centered in that it assumes firms play a central role in responding to institutional pressures and, in acting both individually and in concert, contribution to overall societal outcomes (ibid.; Whitley 1999). This research is founded on such assumptions in that we explore the relationship between setting and overall CSR outcomes, which, of necessity, 
must have been the result of decisions by significant numbers of firms to adopt particular patterns of behavior (c.f. Wood et al. 2014). At the same time, we recognize that a closer analysis of CSR behavior at the level of the individual firm would yield a much nuanced and diverse picture, with potentially the choices of large players, or those concentrated within specific regions, outweighing those of others.

More specifically, the paper aims to explore in more detail whether CSR is more likely to be promoted through shareholder primary, which is a characteristic of developed Common Law countries/LMEs, or in contexts where institutional mediation between different sets of stakeholder interests is more pronounced (developed Civil Law/CMEs). Based on composite indices created for 98 countries around the world, we use linear regression analysis to test hypotheses examining impact of legal origin and corruption control on voluntary CSR dimensions. The paper examines voluntary CSR by two dimensions based on composite indices created: socially responsible investment (SRI) and charitable giving index. Hence, we estimate two sets of regression models which also include interactions between different control variables.

The remainder of this paper is structured as follows. In the next section we provide a critical review of relevant literature on institutional theory, comparative institutionalism and CSR that serves as a basis for development of our hypotheses. Further, the paper's methodology is outlined and this is followed by the discussion of study results and their implication for our proposed hypotheses. The last section provides a conclusion and outlines avenues for future research.

\section{Review of relevant literature}

\subsection{Forms of Comparative Institutional Analysis and Stakeholder Allocations}

In this paper, we deploy the categorizations developed by La Porta et al. (1998) from within the rational-hierarchical literature, which remains one of the most influential ways of comparing national systems across the developing and developed world. La Porta et al. $(1998 ; 2000)$ contend that it is legal origin that determines private property rights. In practical terms, this means that in Common Law countries, shareholders are more likely 
to be able to reign in managers and ensure that they adhere to a value maximization agenda (ibid.); hence, such contexts may be referred to as shareholder dominant. In contrast, in Civil Law countries, the greater rights accorded to other stakeholders means that shareholders cannot be assured of their dominance, or that their profit maximization agenda will be rigorously followed by managers (La Porta et al. 1998). Within the most developed countries, these categories broadly correspond with the well-known liberal market economy/coordinated market economy dichotomy of the Hall and Soskice (2001) Varieties of Capitalism approach, although the legal origin approach is more easily extended to cover the developing world, and transitional economies. Table 1 summarizes their categorization of different countries according to legal origin. La Porta et al. (1998) suggest that French Civil Law origin countries come closest to the Civil Law ideal, followed by German and then Scandinavian law.

\section{[Insert Table 1 about here]}

In line with the mainstream economics and finance literature, La Porta et al. $(1998 ; 2000)$ hold that, if left to their own devices, managers will drift away from the shareholder value maximization agenda, to engage in empire building, in the interests of personal reward and prestige. In doing this, they will naturally seek to collude with employees and other stakeholders (Botero et al., 2004). This approach assumes that stakeholder and owner rights are a zero sum game (Goergen et al., 2009). Should one side win, the other will invariably lose out (ibid.). This argument is a development of the basic Friedmanite idea that the usage of firm resources on CSR represents a misdirection of what rightly belongs to shareholders.

Botero et al. (2004) argue that in Common Law systems, firms divert resources to promote the well being of non-owner interest groupings through two basic mechanisms. The first is 'neglect'; owners simply have less legal clout to supervise managers as their agents, allowing the latter to divert organizational resources in unproductive directions (Botero et al., 2004; La Porta et al., 2000). The second is through active legal compulsion. Botero et al. (2004) argue that laws governing worker rights (and, by 
implication, those of other stakeholders) will tend to be particularly strong in contexts where formal owner rights are weak. In other words, not only in such contexts do owners have weaker formal private property rights, but also they are likely to be further diluted by other legislation, reinforcing the Civil Law legal tradition. Conversely, in Common Law countries, there is likely to be less legislation compelling owners to direct more resources to other stakeholder groupings.

\subsection{Setting and Corporate Social Responsibility (CSR)}

In making strategic choices firms are directed both through formal rules and informal conventions and pressures (Amable 2003, p.34; North, 1990). Matten and Moon (2008) posit that within the owner dominant Common Law settings explicit CSR is more common, and in Civil Law contexts, where stakeholder rights are stronger, implicit CSR is more predominant. They define explicit CSR as voluntary initiatives and strategies "which combine social and business value" (Matten and Moon 2008, p.409). In other words, they are both a 'gift' of the firm that may be withdrawn at any time, and their rationale may combine a desire to contribute to society with hard-nosed business logic. Implicit CSR is where firms are impelled by formal and informal institutions to address issues of concern by stakeholders (ibid.). In other words, socially responsible behavior will not solely reflect the law; in addition to formal regulation, informal rules and conventions are likely to determine CSR outcomes. This would suggest the need for close attention to be paid to possible differences between voluntary and involuntary or systemically implicit dimensions of CSR when making usage of composite measures.

\subsubsection{Responsible Stakeholder Capitalism (or the Mediating Effects of Civil} Law)

It can be argued that in contexts where owner rights are mediated by those of other stakeholders, firms are more likely to be socially responsible (Jackson and Apostolakou 2010). A key feature of Civil Law countries is that power is divided between a wide range of interest groupings. For instance, institutional theorists assert that in contexts with 
stronger rights bestowed to other stakeholders and interest groups, institutional actors such as nongovernmental organizations (NGOs) can be particularly effective and successful in monitoring corporate behaviour, influencing the policy-making process, and thus exerting pressure on firms to be more socially responsible (Campbell, 2006).

It is also acknowledged that specific stakeholder orientated Civil Law countries for example, Germany and the Scandinavian countries - are leaders when it comes to environmental responsibility (c.f. Lynes and Andrachuk 2008). Strong welfarist policies encourage firms to adopt high standards, resulting in a superior environmental and social performance (Gjølberg 2009, p.610). It has been further suggested that the systemic mediation of corporate power with stakeholder interests allows for the adoption of a longer-term view that necessarily encompasses issues of environmental sustainability and responsible investing (ibid.). Hence, firms are more likely to promote employment conditions that contribute to employee well-being, more responsible relations with customers and suppliers, and more environmentally friendly business practices (Gjølberg 2009). The branch of organisational institutionalism, which places more focus on societal norms, emphasises that such socially responsible behaviour may be more pronounced in Civil Law contexts also because of embedded normative standards in such environments, where organizations have "implicit commitment" to act in more socially responsible ways to other stakeholders (Campbell, 2006, p.933; Matten and Moon, 2008).

\subsubsection{Owner Rights and CSR}

Within the finance literature, a dominant strand of thinking suggests that when property rights are stronger (i.e. Common Law countries), shareholders will be better equipped to restrain managers from excessive empire building, and the vanity projects (La Porta et al. 1998; 2000). Although CSR spend does not necessarily denote an agency failing, certain types of CSR spending may do so. Essentially, it is held that the business of business is to make money, with inappropriate CSR - that which does not immediately contribute to the enhancing the bottom line - being essentially theft of shareholder resources in order for managers to promote themselves and enhance their prestige (Friedman, 1997). 
Economic institutional analysis, through its focus on regulations and institutional design, further suggests that acts of deregulation, which entail decrease in monitoring and enforcement activities, may reduce organizations' socially responsible behaviour and even result in some behaving in socially irresponsible ways (Campbell, 2006; 2007; North, 1990; Demirbag, Frecknall-Hughes, Glaister, and Tatoglu, 2013). Thus, it could further be argued that in Common Law countries, less attention will be devoted to socially responsible activities, not only on account of formal regulation, but also because of generally weaker formal ties between stakeholders, and more limited discretion accorded to management to pursue agendas other than profit maximization. Less encompassing institutional frameworks lead to organizations doing little more than the bare minimum (see De Castro et al., 1996; O’Hagan, 2002). Organizations that act in a responsible manner are likely to face the constant undercutting of their position by less principled competitors, forcing a 'race to the bottom' (Mellahi and Wood, 2004a). 'Soft rules' on their own are unlikely to be able to deter opportunism (ibid.). As owners face fewer institutional constraints, they are more likely to pursue narrow short-term interests in investment decisions (Gourevitch and Shinn 2006). These discussions inform our first hypothesis:

Hypothesis 1. In Common Law (owner-dominant) settings, overall levels of social responsibility will be lower than in Civil Law Countries.

Alternatively, it could be argued that CSR can assume greater importance in liberal markets. Within common law countries the state cannot be relied on to the same extent to stabilize relations between communities and firms through providing a durable social infrastructure (Habermas, 1976; Mellahi and Wood, 2004b). Yet, some dialogue and trust is necessary to make exchange relations work (ibid.). Hence, corporate philanthropy emerged and persisted "as an ideological movement intended to legitimize the power of large corporations" (c.f. Mitchell, 1989; Oberman, 2000, p.239). Jackson and Apostolakou (2010) argue that, in the developed Common Law countries (LMEs), firms are likely to be more socially responsible in CSR, reflecting primarily instrumental motives on the behalf of firms, who are particularly sensitive to investor and customer 
pressures, and whose room for maneuver is less restricted by insider interests (that is, managers or workers) within the firm (see also: Aguilera et al, 2006). Given this, it could be argued that firms are more likely to implement measures that are prompted by specific and immediate crises of legitimacy. Such measures could encompass 'greenwashing', centering on environmental marketing and the high profile adoption of a limited range of environmental measures than a comprehensive change in policies (Mellahi and Wood, 2004a; 2004b; Mellahi et al. 2010). Existing literature would suggest such practices are indeed more common in contexts where property owner rights are the strongest and/or the legitimation crisis particularly severe (Burnell and Ware, 2007; Hearit, 1995; McCarthy and Puffer, 2008).

To put it differently, firms are more likely to implement measures that are prompted by specific and immediate crises of legitimacy. Most typically, this takes the form of charitable or quasi-charitable giving (Mellahi, et al. 2010). An example of the latter would be junk food manufacturers making highly publicized, yet carefully calculated, donations to schools and to promoting children's sports (c.f. ibid.). Others would be oil companies making donations to ostensibly independent charitable foundations or NGOs that focus on denying global warming, and pharmaceutical companies to 'patient rights' groupings that vocificerously demand state funding for expensive drug cures. Similarly, instrumental and widespread are donations to charitable foundations or think tanks with close links to specific political parties. Giving to more objectively charitable causes may also serve instrumental motives. Again, an example would be junk food manufacturers sponsoring international sporting events to encourage an association of their brand with health, well-being and athletic prowess.

Furthermore, it could be asserted that in such contexts firms may be more socially responsible for reasons other than simply legitimation. Firstly, socially responsible investing has been promoted as good for business (Hill et. al. 2007), and hence, it could be argued that it is more likely to be encountered in lightly regulated contexts where property owners are freest to pursue new opportunities as and when they arise. Socially responsible investing may represent a sound business decision, given the increased consumer demand for responsibly sourced products (c.f. Klassen and McLaughlin 1996). Secondly, within contexts where property owner rights are weaker, resources have to be 
shared across a wide range of entrenched stakeholder interests. This may make it difficult to divert resources towards new directions (Jackson and Apostolakou 2010). For example, organized labour may be hostile if a proportion of the share of resources potentially allocatable to workers is diverted to meet an increasingly important environmental agenda. Any benefits accruing from the latter are likely to be spread across society at large, whilst the upfront costs will be shouldered by the immediate stakeholders in the firm.

Thus, whilst owners may be better equipped to prevent managers from directing resources away from immediate profits, they may be forced to do so in order to overcome legitimation crises generated by the system (Habermas, 1976; Hearit, 1995). In other words, whilst firms may be less inclined to engage in a range of socially responsible behavior, they are nonetheless likely to do so in a single area, charitable giving. This aims to enhance the firm's political clout, facilitate marketing and generally enhance the image of the firm in order to offset instances of adverse publicity. As noted earlier, Matten and Moon (2008) argue that in liberal market/shareholder dominant contexts firms are likely to practice explicit CSR, choosing to give in a manner that often is nonetheless at least partially informed by profitability concerns. This argumentation results in our second hypothesis:

Hypothesis 2. Voluntary charitable giving is likely to be more pronounced in Common Law countries than in Civil Law ones.

\subsection{Corruption and Social Responsibility}

Whilst socialist legal origin might suggest particularly weak property owner rights, such countries are undergoing a protracted and complex transition process that may make such a categorization no longer useful. La Porta et al. (2008) acknowledge this, by suggesting that such systems are drifting back to the German civil law roots. Other accounts, such as Lane and Myant (2006), highlight the very protracted nature of the transition these economies are undergoing and the extent to which institutional coverage remains fluid and shifting. Again, within much of the developing world, there is a distinction between 
formal institutional configurations and institutional capabilities on the ground (Wood and Frynas, 2006). In both instances, fluidity and uneven institutional coverage opens greater opportunities for corruption, allowing firms to buy their way out of regulations deemed burdensome, but at the same time, opening up legitimacy crises. Hence, we explore the effects of corruption on CSR, as this sheds further light on the distinctions between societies with broadly similar legal frameworks, but with important distinctions in terms of how rules operate on the ground.

A neglected dimension of institutional theory and CSR is the relationship between corruption control and CSR activities. Some studies have shown that good corporate governance is not possible in an environment of deep-seated corruption (Black \& Tarassova, 2003; Mellahi et al., 2012). While institutional factors help to establish the rules of the game through which firms gain legitimacy in the marketplace, corruption distorts these rules (Luo, 2006; Rodriguez et al., 2006). When corruption is not controlled by institutional mechanisms, firms may be forced to control cost and therefore allocate fewer resources for social purposes. In the absence of high corruption, however, firms will be more lenient for social and philanthropic purposes (Baughn et al., 2007; Luo, 2006). Therefore, it is argued that illicit acts in a corrupt environment increase transaction costs for firms and jeopardize their CSR activities and re-investment (Demirbag et. al. 2015; Wood and Demirbag, 2015). Countries, on the other hand, have different norms and standards concerning corrupt practices. For instance, it is argued that bribery or kickbacks are often culturally ingrained as an acceptable practice (Luo, 2006). As Luo (2006) further argues, firms' philanthropic contribution to society may decrease in response to increased corruption perception. The logic behind this argument is based on Giddens structuration theory. It is asserted that corporate philanthropic contributions may decrease if there are no incentives for CSR activities. Fear of governmental and political embezzlement may reduce philanthropic contributions and hence CSR activities in a highly corrupt environment (Luo, 2006). Campbell (2006) further argues that the pattern of interaction between firms and their stakeholders is very important for managers' perception of their business environment. Firms' political behavior, therefore, is inseparable from managers' corruption perception in a country. Thus, our third hypothesis is as follows: 
Hypothesis 3. CSR activities will be more pronounced in countries where managers perceive higher corruption control by institutional mechanisms.

\section{Methodology}

\subsection{Data}

In this paper, we use two different sources of data to examine CSR activities, both of which are based on surveys of executives and individuals. We would argue that CSR is a multifaceted concept therefore requires examination through different dimensions. Due to the nature of this study, our measures incorporate the first and third approach as summarized in the previous paragraph. Therefore, we use two different sources of data to capture two different dimensions of CSR, namely socially responsible investment (SRI) and voluntary giving. These two indices are composite measures which aim to capture multifaceted nature of the concept we examine in this study. Details of these two data sources and created indices are explained in the following section.

Data set used in this paper is compiled from three different sources. The nature of our research question requires a global or a dataset covers a significant proportion of countries around the world. There is no single database to cover voluntary CSR practices around the world. Secondly, we aim to examine different legal system's impact on voluntary CSR dimensions. World Competitiveness report is a comprehensive global report produced annually, and it has been used by a number of studies for different research questions (Fogel, 2006; Van de Vliert, 2003; Chan, Isobe and Makino, 2008; Demirbag and Glaister, 2010). It provides data on CSR activities in general, but particularly on socially responsible investment in its 2005 edition. World giving survey has started at a global level only after 2010, which enabled us to cover a second dimension of voluntary CSR. We also use world governance indicators by World Bank, which enables us to control for income, corruption control level in countries included in 
this study. Similarly, this is a widely used in studies of global or comparative nature and considered to be a highly reliable data source (Ault and Spicer, 2014).

In total, we cover 98 countries in this study. A distribution of these countries by their legal origin is provided in table 1. Voluntary CSR related data (SRI) was compiled from the Global Competitiveness Report (Porter et al., 2004; 2005). Country giving index (world giving index percentage score for each country) was compiled from the World Giving Index (2010). This is the earliest year for data collection on voluntary giving at a global scale; hence we could not go as far as back to 2005. Since we are using the giving index as a separate dependent variable to test a different dimension, having two different data collection dates do not affect our results as each of these indices are used in different regression models. We further explored the relationship between corruption control and propensity to engage in socially responsible behavior; greater corruption is likely to promote irresponsibility in other areas (Satter, 2004). Corruption control related data were compiled from the World Bank's Worldwide Governance Index, which reports aggregate and individual governance indicators globally over the period of 1996-2010 (World Bank, 2010). Legal systems of countries sampled in this study were created based on La Porta et al. (1998) and Botero et al (2004) and authors' own research. La Porta et al., (1998) and Botero et al. (2004) classify 85 countries according to their legal origin. We used CIA's The world fact book (https://www.cia.gov/library/publications/theworld-factbook/), and The Cornel University Legal Information Institute (https://www.law.cornell.edu/wex/legal_systems) to identify legal origins of remaining 13 counties included in our sample for analyses.

The following section describes how variables were compiled and calculated from these three different sources.

\subsection{Variables}

Brammer et al. (2008) argue that genuine social responsibility is difficult to measure; it is hard to disentangle what is really voluntary, and the underlying motives for it (c.f. 
Jackson and Apostolakou 2010; Hopkins, 2005; Turker, 2008). Firms may do 'good deeds' for the wrong reasons. In contrast, Singer (1995) argues that the motivations do not matter; what matters is the end result, and whether the overall well being of society (and the planet) is advanced through such actions. In this paper, we assume the latter, as it is the only feasible starting point for comparing cross-national data, although we recognize the limitations of an inherently utilitarian starting point. Abbott and Monsen (1979) argue that there are three measures for social responsibility. The first is the extent of social reporting, the recording of activities that have some or other socially responsible dimension. However, the challenge here is to have an objective measure of socially responsible activities and attributes. The second is reputational surveys, where individuals are asked to rank the CSR ranking of individual corporations (ibid.: p.503). However, this assumes survey respondents possess good information as to the activities of specific firms (ibid.). A third is content analysis of media reports, and or the attention and detail given to reporting CSR activities in annual reports (ibid.: p.504). The third and first dimension both incorporate a number of sub possible areas. These could include environmental issues, health and safety, equal opportunities, product safety and disclosure (ibid.: p. 505). Marquez and Fombrun (2005: p.306) provides a similar list, but also adds community relations, and international activities. There are several ratings agencies who compile rankings of individual firms based on such measures; however, some very controversial companies do relatively well in certain rankings, and there is much debate surrounding the validity of metrics of responsibility compiled for commercial ends (c.f. Marquez and Fombrun, 2005). Moreover, such ratings often lack proper theoretical justification (Turker 2008: p. 414).

\subsubsection{Dependent variables}

Socially Responsible Investment (SRI): The first CSR dimension this paper focuses on is socially responsible investing (SRI), which is rapidly growing in developed and developing economies and considered as a key feature of CSR activity (Hill et al, 2007; Krumsick, 2003). SRI can be broadly conceptualized as the relative propensity of the firm to embed financial objectives in ethical and social commitments (Munoz-Torres et al, 2004). In this light, it can be argued that SRI represents a concrete diversion of 
resources towards economic, social and ethical ends and can be therefore considered as a particularly good measure of genuine commitment of the firm to social and ethical values (Sparkes and Cowton 2004). Within the bracket of socially responsible investment is the environmental dimension that experienced growing interest of CSR practitioners and academics alike (Baughn et al, 2007; Ioannou and Serafeim, 2014; Klassen and McLaughlin 1996). We use the index of voluntary SRI practices of companies reported in the Global Competitiveness Report (Porter et al., 2005). This a composite index of several variables that incorporate a voluntary dimension. These variables are: 'prevalence and effectiveness of environmental reporting', 'prevalence of environmental marketing', 'prevalence of environmental management systems', 'prevalence of corporate environmental reporting', 'importance of environmental management for companies', 'prioritization of energy efficiency', 'importance of environment in business planning', and 'prevalence of socially responsible investing'. A composite index was created by a factor analysis of these variables (table 2 and the index was labeled as country SRI index. The SRI index appears to have a high reliability (Crombach's alpha:0.98) and explanatory power (a total explained variance of $89.9 \%$ ).

\section{[Insert Table 2 over here]}

Charitable giving: The second dependent variable used in this paper aims to capture another voluntary dimension. Many dimensions of CSR behavior incorporate both voluntary and involuntary practices, making it difficult to discern if a practice follows strictly the ethical ethos of improving the social and ethical life of relevant stakeholders and the society in general, or if it is an involuntary product of context specific rules and obligations (Brown and Forster, 2013). Whilst SRI and environmental issues may often be the product of the latter, charitable giving represents a relatively 'free' choice of firms. In this way it can be argued that charitable giving readily deploys to suit instrumental concerns, and has assumed greater importance given the erosion of institutionalized solidarity within such contexts (see Brammer et al. 2008; 2012; Godfrey, 2005). Hence, this article argues that a caveat is in order here. There is not necessarily a rigid dichotomy between charitable giving and other forms of corporate philanthropy. Shareholders or 
owners may believe in the genuine worth of a particular cause, whilst other measures, for example, environmental ones, may make for both more effective resource utilization and enhance corporate reputation. At the same time, in contexts where there is a strong emphasis on shareholder value, it is likely that, at least in part, voluntaristic corporate practices are particularly likely to be prompted by concerns for the bottom line (see Goergen et al. 2009; La Porta et al. 1998; Roe 2003). Charitable giving (giving index percentage score) was compiled from World Giving Index created by Charities Aid Foundation (CAF, 2010). World Giving Index takes into account all three charitable behaviors in the survey (CAF, 2010). These are whether the respondent donated money to an organization, volunteered time to an organization, and helped a stranger or someone they did not know who needed help (CAF, 2010). The giving index has been created by calculating an average of the three measures in order to come up with an overall country score.

\subsubsection{Independent variables}

\section{Corruption Control (log corruption):}

Corruption control is one of six composite indices created to measure governance around the world by the World Bank. Worldwide Governance Indicators are also known as Kauffman's index. The WGI draw on data from 31 different sources that provide information on various aspects of governance (http://info.worldbank.org/governance/wgi/resources.htm). We used log transformed version of this measure in regression models.

\section{Legal Systems:}

These are dummy variables created for countries covered in this paper. Legal systems of countries were classified into one of the five groups used by La Porta et al. (1998) and Botero et al (2004).

\subsubsection{Control Variables}


GDP per capita in terms of purchasing power: We use GDP per capita in purchasing power from the World Bank (2005 and 2010). We used the log transformed version of this measure in regression models.

High SRI: The regression model has a dummy called "high" which takes a value one if SRI index is high (in this case positive) and a value of zero if SRI index is low (negative). The reason 0 is the cut off value comes from the distribution of SRI: Mean $=0$, Median $=$ $-0.08, \min =-2.31, \max =2.30$. A rough Gaussian distribution of the variable centered around 0 , and hence we use this as the threshold.

Our analyses indicated that there are high level of correlations between GDP per capita, corruption, and many other country level variables therefore we decided to use only GDP per capita (purchasing power) and high SRI as control variables. High correlations suggest the new variables may add little explanation in regression models (Knack and Keefer, 1995). Studies of similar nature reported high level of correlations between country level variables (Lancee and Van de Werfhorst, 2012).

\section{Results}

Table 3 shows descriptive statistics and correlation coefficients of dependent and independent variables in the study. The pairwise correlations do not seem to present serious multicollinearity problems for the multivariate analysis, as none of the variables have correlation that might distort estimation.

\section{[Insert Table 3 over here]}

In order to examine the impact of institutional level factors (corruption control and legal origin) on voluntary CSR dimensions, 6 regression models were estimated with the dependent variables being voluntary SRI index and giving index. The effects of independent variables on each of the dependent variables of voluntary SRI and voluntary giving indices are shown in tables 4 and 5, respectively. 


\section{[Insert Table 4 and 5 over here]}

The effects of independent variables on SRI index were tested in models 1,2 and 3 of table 4. In model 2 of table 4, we examine interaction effect between high SRI and log of GDP per capita which is measured by purchasing power (PPP). Similarly, the interaction of high SRI and corruption control (log corruption) is tested in model 3 of table 4 . In both models 2 and 3 (in table 4) we use a dummy called "high" which takes a value of one if SRI index is high (in this case positive) and a value of zero if SRI index is low (negative). For each of the regression models, variance inflation factors (VIF) were examined to determine the existence of multicollinearity. None of the VIF scores were above 2.9, indicating that multicollinearity is not a problem with these data (Hair et al., 2006).

The model 1 of table 4 reveals that Scandinavian legal system has the highest effect on voluntary SRI index $(\beta=1.447 ; \mathrm{p} \leq 0.000)$ while it is followed by the German legal system $(\beta=1.404 ; \mathrm{p}<0.000)$ which corroborates H1. The English legal system appears to have the least impact on SRI index $(\beta=0.587 ; \mathrm{p}<0.000)$. The (state) socialist legal origin system on the other hand, does not have any statistically significant effect on voluntary SRI index in this model. The corruption control index appears to have a high impact on voluntary SRI index of countries sampled for this study $((\beta=0.890 ; p<0.000)$. In other words, in countries where corruption is more closely controlled, firms are more likely to be socially responsible, hence providing partial support to $\mathrm{H} 3$.

In order to examine differences between the high and the low SRI index countries we create an artificial control group (in this case high SRI countries) to see if the main effects change compared to the whole sample. Therefore, we test the interaction of $\operatorname{logGDP}$ with the dummy variable created for high SRI index countries (high), but the dummy variable itself is not included in the regression. This interaction tests to see if the effect of $\log$ GDP on SRI index changes if we consider only those countries where SRI index (therefore the level of CSR adoption) is high. We see there is very little change in the way all variables affect SRI index, except that the magnitude of logGDP coefficient is now smaller $(0.285<0.490)$. Similarly, we examine the interaction effect of high SRI adoption with corruption control (high*logCorr), once again, there is very little change, 
except that the impact of $\log$ Corr is lower $(0.666<0.89)$. Both sets of interactions show that the impact of the key variables, logGDP and logCorr have a reduced impact for high SRI adoption countries compared to low SRI adoption countries. This is something similar to a nonlinear (concave) impact.

In models 4, 5 and 6 of table 5 however, we test independent variables impact on voluntary giving index. Models in table 5 display a similar pattern to models presented in table 4 albeit with some changes in signs of coefficients. Coefficients of English/Common Law legal origin and corruption control in Model 4 are both positive and significant $(\mathrm{p}<0.000)$ indicating that the English/Common Law legal origin creates the highest voluntary giving, hence confirming $\mathrm{H} 2$. The state socialist legal origin system however shows a negative signed coefficient which implies that it has a negative impact on voluntary giving index. Surprisingly, both the German and the Scandinavian legal system do not seem to have any statistically significant impact on voluntary giving index. The interaction effect of $\log$ GNP with "high" which shows once again that the impact of $\log$ GNP is decreased for countries with higher values of SRI index $(1.39<9.22)$. We also examine the interaction effect of logCorr with higher values of SRI, but, in this instance, neither the main effect of $\log$ Corr nor the interaction are significant.

\section{Discussion}

As suggested by the first hypothesis, there is a relationship between institutional context, and, more explicitly, legal origin - and implicitly shareholder vs. stakeholder rights - and CSR. And, reflecting stronger shareholder rights (and, possibly, a greater restraint on the pursuit of esteem and prestige by managers), organizations operating in contexts with a Common Law legal origin give significantly less attention to CSR. Hence, Hypothesis 1 is supported.

However, the direction of causality is not strictly on the lines suggested by La Porta and colleagues $(1998 ; 2000)$. More specifically, the latter would suggest that firms would disburse more organizational resources in directions other than for the narrow pursuit of immediate shareholder value in contexts where owner rights were weakest. Hence, CSR should be more prominent in French Civil Law ones than German or 
Scandinavian ones, which infuse some features of Common Law; Scandinavian law represents the Civil Law orientated system where shareholder rights are the strongest (albeit still weaker than Common Law). Why would this be the case? La Porta et al's (1998; 2000) approach, as noted earlier, is a rational hierarchical one, where owner and other stakeholder rights represent a zero sum game (Goergen et al., 2009). This approach discounts the possibility of complementarity, of win-win situations where the sum of inputs is greater than a review of their component parts would suggest. Although Amable's (2003) country distinctions broadly respond to those of La Porta et al (1998), the former, derived from cluster analysis of a wide range of societal and economic metrics, sees them as discrete categories; this would suggest that, rather than being diluted Civil Law systems that accord relatively more rights to property owners, the Scandinavian countries are associated with particularly well-developed accommodations between shareholders and other stakeholders, that constrain their ability to act autonomously of each other, yet allow for synergies, whereby each side can gain benefits greater than if they had selfishly pursued their individual interests. Again, Germany and the Rhineland economies more generally - are depicted by the literature on comparative capitalism to be associated with more deeply embedded stakeholder rights than in France and other countries with classic French civil law systems (Amable 2003; Hall and Soskice 2001). Again, this would suggest that, contrary to La Porta et al. (2008), the strongest stakeholder rights (and, by implication higher levels of social responsibility) are not necessarily a reflection of weak owner rights or institutional inefficiencies; it is possible for accommodations between the two to take place, made possible by complementarity (Hall and Soskice, 2001).

Engaging in socially responsible activities do not necessarily mean that shareholders lose out, even if the reasons for their adoption are not strictly instrumental. For example, it is possible that some investors may assume that part of their duty is to promote local economic development and sustainability (e.g. some of the shareholders of the Volkswagen group; the Robert Bosch Foundation), whilst performing such a role may in turn, facilitate in building customer loyalty within the said region. Similarly, ethical investors may demand high standards of health and safety as a desirable goal in its own right, which, in turn, may enhance employee commitment, with ultimate productivity 
gains. The research revealed that, in some institutional settings, such complementarities appear more likely (Wood and Frynas, 2006; Wood, Dibben, and Ogden, 2014). However, it is also apparent that there is considerably more that defines setting than simply property owner rights. This is particularly so since categories such as the 'purer' French Civil Law tradition are very diverse ones, encompassing countries at a wide range of stages of development, and with considerable variations in the capabilities of the state to enforce legislation.

However, the clear patterns that emerged when comparing differences between countries in Western Europe were less apparent in looking at post-state-socialist centraleastern Europe. More specifically, we found that a socialist legal origin system did not have impact on voluntary CSR activities. There are two possible explanations for this. The first is that categories such as '(state) socialist legal origin' or 'transitional' are not very helpful in looking at countries within the region. Such categories assume strong path dependence and discount the very real changes that have taken place within different countries some twenty five years after the end of state socialist rule. There is a considerable body of literature that suggests that some countries have converged with more mature capitalist archetypes. For example, there is a growing body of literature that concludes that Estonia and other Baltic Republics are now a full-fledged LME or shareholder dominant model, and Slovenia a CME or stakeholder model, differences in legal origin notwithstanding (Alas and Tafel, 2008; Kovaliov and Streimikiene, 2008; Lane and Myant, 2006; Mygind et al, 2006; Übius and Alas, 2010).

It has been argued that during the transition CSR basically evolved as a response of business to globalization, moulded by specific circumstances (Mizobata, 2010; Polishchuk, 2009). Privatization significantly affected the form CSR assumed, but varying according to country. In some cases like Russia, privatization was particularly dramatic. Such "big bang" privatization (Chen, 2009) greatly traumatized the Russian population who correctly perceived the outcomes as a deeply unfair deal. This brought great mistrust in government and, even more so, in big businesses with consequent serious legitimation crisis (Kuznetsov, et al 2008). In other countries like Slovenia, Baltic Republics, etc., the process was less traumatic due to their generally better economic situation (Mygind et al 2006). Even if the privatization process undergone varied, the 
transition to the market economy brought a general and deep rethinking of the role of all stakeholders, and the state in particular.

For reasons noted above, legitimation crises may result in some highly focused CSR activities. Within criminal states in the region - a category that would almost certainly encompass Russia, Moldova, Ukraine, Kosovo, and possibly Serbia - high profile individuals, engaged in large-scale primitive expropriation, and then sought to entrench their right to ill-gotten gains through conspicuous philanthropic projects. The latter has ranged from the restoration or building of Orthodox churches to 'giving' financial handouts to highly peripheralized clans, urban centres or even entire regions (Satter, 2004). Mizobata rightly points at the dual character of philanthropy in Russia acting as public policy and business strategy. (Mizobata, 2010, p14). In countries with weak institutional environment and low level of law observance, it seems natural that CSR perception would be quite different from the one adopted in Western countries, and, in can be argued, more akin to 'public relations exercises' (Kuznetsov et al, 2009).

This leads us on to our second hypothesis. As suggested by legitimation approaches, charitable giving was most pronounced in Common Law legal systems. It is likely that legitimacy gaps prompting such giving were, at least in part, a lack of willingness to engage in responsible behavior in other areas. In contrast, in Civil Law contexts, there was not a statistically significant relationship between legal family branch (e.g. German, Scandinavian) and proclivity towards charitable giving. This would probably reflect the outcome of different counter-tendencies. The first is that firms in such contexts are less likely to be prompted into charitable giving by legitimacy concerns. Closer and denser ties with a wide range of stakeholders mean that the firm is more likely to take account of their wishes in the first place. Second, and opposed to this, taking account of shareholder concerns will, of necessity, involve allocating some organizational resources and/or capabilities to meeting their concerns, which may or may not entail charitable giving.

But, given the relationship between a Common Law legal origin and charitable giving, what about other settings where legitimacy crises are likely to be encountered? In countries with a socialist legal origin, charitable giving was the least, although this finding appears to mask a great deal of internal diversity. Within most national contexts 
in the region, painful economic reforms have imposed great austerity, forcing many established firms into bitter battles for survival, with meager profits limiting the capacity to give. But, within the criminal periphery, legitimacy-prompted charitable giving is likely to be more significant, but instrumentally focused, cost effective, and short-termist than in Common Law contexts, where a somewhat longer-term view is possible (c.f. Satter, 2004). As Matten and Moon (2008) note, weak civil society and a parasitic relationship between firms and government may combine with a lack of a tradition of responsible conduct by firms to militate against social responsible behavior; indeed, in very corrupt contexts, there are strong disincentives to altruism in that gifts may be easily misappropriated (Satter, 2004). A culture of pervasive corruption may serve to debase behavior in other areas. Indeed, we found that in countries where corruption is more closely controlled, firms are more likely to be socially responsible, broadly proving our third hypothesis. At the same time, the regression coefficients on the relationship between corruption and voluntary giving are highly diffuse. This could reflect the extent to which there are counter-incentives: donations to causes favoured by corrupt elites could provide one channel for firms to curry favour with politicians.

There are certain limitations to this research, which serve to highlight possible future directions and priorities. Firstly, the usage of La Porta et al's $(1998 ; 2000)$ measure of owner and stakeholder rights is not unproblematic (Armour et al., 2009a; 2009b). In particular, it assumes a very strong path dependence, which discounts the possibilities for major institutional redesign, or for one institutional archetype to converge with another. Indeed, La Porta et al. (2008) suggest that state socialist legal origin countries of central and Eastern Europe are drifting back to their Germanic legal origin roots; in contrast, the literature on comparative capitalism would suggest that, some of these economies have moved close to the LME idea (Lane and Myant, 2006). In line with earlier work on comparative institutional analysis, this study focuses on the relationship between context and broad socio-economic level outcomes, approaching the firm as a transmission belt between the two (Hall and Soskice 2001; La Porta et al. 2008; Wood et al., 2014); this enabled the coverage of a very wide range of countries, from many of which, firm level data on CSR is relatively scarce. We recognize that the usage of firm level data would 
provide a very much more nuanced and finely grained picture, and that this constitutes a further limitation of this research.

It is also apparent that there is considerably more that defines setting than simply property owner rights. Why then did we not employ one of the alternative country categorizations devised within the literature on comparative capitalism? As noted above, varieties of capitalism approaches have historically been dichotomous and orientated towards the most developed countries, with only limited attention being accorded to systems that strictly conform neither to the shareholder/liberal market or stakeholder/coordinated archetypes, nor to the great diversity within the latter category (Aguilera and Jackson, 2010; Dore, 2000; Hall and Soskice, 2001). Again, multi-variety approaches (see for example, Amable, 2003; Whitley, 1999) remain Eurocentric, limiting their applicability elsewhere, and, within Western and Southern Europe, Amable's categories in any event broadly correspond with those of La Porta et al (2008), France excluded. Moreover, a focus only on Europe would make it difficult to draw conclusions on the relationship between shareholder dominant setting and CSR, given the relatively few examples of such systems on the continent.. Finally, this study does not explore changes over time. However, whilst more pessimistic accounts of institutional change in more stakeholder orientated institutional settings suggest systemic decay (Streeck 2009), the research found continued difference between context and practice; in general, firms in stakeholder orientated settings remained more responsible than those in shareholder dominant ones.

\section{Conclusion}

The research revealed a close relationship between institutional setting and corporate social responsibility. More specifically, within contexts where owner rights were stronger, firms were less likely to spend more on a range of voluntary CSR measures. However, the converse is not directly true. In national contexts where the Civil Law ideal is most pronounced, that is those of French legal sub-family, voluntary CSR spending (whilst significantly more than in shareholder dominant rights settings) is less than in more mixed or diluted Civil Law traditions, such as Scandinavian or German law. 
In part this could be accounted for by the sheer diversity of the former category, but it is also likely to reflect the possibilities of complementarity. For example, within the German context, large manufacturing firms reap the benefits of high productivity that comes with strong employee commitment; in part, this reflects superior terms and conditions of service, but also safe and pleasant working environments, and close ties between firms and communities.

In short, firms operating in Common Law contexts are less likely to take CSR seriously. However, there is one exception to this general rule, in the area of voluntary charitable giving. Countries of Common Law legal origin - that is where owner rights are strongest - are more likely to engage in the former. Firms in such contexts are most likely to be closely orientated to maximizing shareholder value, with managers having relatively less discretion to direct organizational resources in other directions. Given this, it is likely that giving will be instrumentally intended to promote profitability, to facilitate marketing and/or resolve wider crises of legitimacy. In contrast, in contexts where owner rights are weaker, managers have greater autonomy to direct organizational resources in directions other than the maximization of shareholder value. What this finding points to is confirm the tension between business-driven and multi-stakeholder forms of CSR (Brammer et al. 2012). An epitome of the former is charitable giving especially when used to promote causes that serve corporate interests and/or provide legitimacy, and of the latter environmental responsibility, in other words, that the firm seeks to reduce the externalization of the costs of its activities on the community at large.

Whilst we did encounter significant differences between Civil Law and Common Law systems, no clear pattern emerged between (state) socialist legal origin and the propensity of firms to engage in CSR. It is likely that this reflects the diversity of this category, and the extent to which countries in the region have diverged into different paths (Lane and Myant, 2006). In some, property owner rights have become stronger, and others, they have become systemically re-mediated through focused institutional redesign. Still others have degenerated into criminal states (Satter 2004). What the region does have in common is that charitable giving is relatively low. This probably reflects the limited resources available to firms battling to cope with external shocks and ongoing crises of competitiveness. It may also, within criminal states, reflect excessive, 
self-destructive, short-termism, in contrast to the more sophisticated approaches of property owners in stable Common Law systems, and the greater ability to co-opt powerful interests to suit corporate agendas, regardless of public pressure. It also highlights the limitations of models that assume strong path dependence, and the need for comparative analysis to incorporate an understanding of the dynamics of systemic change (c.f. Boyer 2006).

The study revealed that the Civil Law stakeholder model retains distinct features, even if as Matten and Moon (2008) suggest, there may be a long-term tendency towards more explicit CSR in the most developed economies in the former category. The same goes for countries that fall into the broad state socialist legal origin category. Finally, we found that socially responsible behavior was more likely in settings where there is a stronger control on corruption; high levels of corruption that go unchecked may well debase behavior in other areas. In other words, if firms are accustomed to being able to buy their way out of problems with regulators, they may feel less need to have to placate the public at large.

\section{Acknowledgement}

We are indebted to the anonymous reviewers for their invaluable comments on previous drafts of this manuscript. 
Table 1 Distribution of sample by legal origin

\begin{tabular}{|c|c|}
\hline Legal Origin & \\
\hline $\begin{array}{l}\text { English Common Law } \\
\text { (30 countries) }\end{array}$ & $\begin{array}{l}\text { Australia, Bangladesh, Botswana, Canada, Cyprus, Ghana, } \\
\text { Hong Kong, India, Ireland, Israel, Jamaica, Kenya, Malawi, } \\
\text { Malaysia, Malta, New Zealand, Namibia, Nigeria, Pakistan, } \\
\text { Singapore, South Africa, Sri Lanka, Tanzania, Thailand, } \\
\text { Trinidad and Tobago, Uganda, United Kingdom, United States, } \\
\text { Zambia, Zimbabwe }\end{array}$ \\
\hline $\begin{array}{l}\text { German Civil Law } \\
\text { (7countries) }\end{array}$ & $\begin{array}{l}\text { Austria, Germany, Japan, South Korea, Luxembourg, } \\
\text { Switzerland, Taiwan }\end{array}$ \\
\hline $\begin{array}{l}\text { Scandinavian Civil } \\
\text { Law ( } 5 \text { countries) }\end{array}$ & Denmark, Finland, Iceland, Norway, Sweden \\
\hline $\begin{array}{l}\text { Civil Law (35 } \\
\text { es) }\end{array}$ & $\begin{array}{l}\text { Algeria, Argentina, Belgium, Bolivia, Brazil, Chad, Chile, } \\
\text { Colombia, Costa Rica, Dominican Republic, Ecuador, Egypt, } \\
\text { France, Gambia, Honduras, Greece, Indonesia, Italy, Jordan, } \\
\text { Madagascar, Mali, Mexico, Morocco, Mozambique, } \\
\text { Netherlands, Panama, Paraguay, Peru, Philippines, Portugal, } \\
\text { Spain, Tunisia, Turkey, Uruguay, Venezuela }\end{array}$ \\
\hline $\begin{array}{l}\text { State socialist origin } \\
(19 \text { countries })\end{array}$ & $\begin{array}{l}\text { Bosnia and Herzegovina, Bulgaria, China, Croatia, Czech } \\
\text { Republic, Estonia, Georgia, Hungary, Latvia, Lithuania, } \\
\text { Macedonia, Poland, Romania, Russian Federation, Serbia, } \\
\text { Slovak Republic, Slovenia, Ukraine, Vietnam }\end{array}$ \\
\hline $\begin{array}{l}\text { Islamic-Civil Law }(2 \\
\text { countries) }\end{array}$ & , United Arab Emirates \\
\hline
\end{tabular}

Sources: La Porta et al. 1998; Botero et al. 2004 and author's own research. 
Table 2: Factor scores for Voluntary CSR- component matrix

\begin{tabular}{|l|l|l|l|}
\hline & $\begin{array}{l}\text { Factor } \\
\text { loadings }\end{array}$ & $\begin{array}{l}\text { Eigen } \\
\text { value }\end{array}$ & $\begin{array}{l}\text { \% of variance } \\
\text { explained }\end{array}$ \\
\hline Prevalence environmental marketing & 0.949 & 6.29 & 89.99 \\
\hline $\begin{array}{l}\text { Prevalence of environmental management } \\
\text { systems }\end{array}$ & 0.935 & 0.946 & \\
\hline $\begin{array}{l}\text { Prevalence of corporate environmental } \\
\text { reporting }\end{array}$ & 0.951 & & \\
\hline $\begin{array}{l}\text { Importance of corporate social } \\
\text { responsibility }\end{array}$ & 0.961 & & \\
\hline Prioritization of energy efficiency & 0.932 & & \\
\hline $\begin{array}{l}\text { Importance of environment in business } \\
\text { planning }\end{array}$ & 0.966 & & \\
\hline Prevalence of socially responsible investing & & & \\
\hline &
\end{tabular}

Crombah's alpha $=0.981$

$\mathrm{KMO}=0.899$

Bartlett's test of sphericity $=1238.27$

Significance $=0.000$ 
Table 3 Correlation matrix

\begin{tabular}{|l|l|l|l|l|l|l|l|l|l|l|l|}
\hline Variables & Mean & SD & $\begin{array}{l}\text { SRI } \\
\text { index }\end{array}$ & $\begin{array}{l}\text { Corruption } \\
\text { control }\end{array}$ & $\begin{array}{l}\text { Giving } \\
\text { index }\end{array}$ & $\begin{array}{l}\text { Log } \\
\text { GDP } \\
\text { per } \\
\text { capita }\end{array}$ & English & German & $\begin{array}{l}\text { Scandina } \\
\text { vian }\end{array}$ & French & Socialist \\
\hline SRI index & 0.00 & 1.00 & 1.00 & & & & & & & & \\
\hline Corruption control & 57.88 & 27.32 & 0.56 & 1.00 & & & & & & & \\
\hline Giving index & 32.11 & 11.52 & 0.45 & 0.21 & 1.00 & & & & & & \\
\hline Log GDP per capita & 4.01 & 0.51 & 0.56 & 0.61 & 0.33 & 1.00 & & & & & \\
\hline English & & & 0.13 & -0.00 & 0.36 & -0.14 & 1.00 & & & & \\
\hline German & & & 0.43 & 0.20 & 0.17 & 0.30 & -0.15 & 1.00 & & & \\
\hline Scandinavian & & & 0.38 & 0.23 & 0.18 & 0.35 & -0.13 & -0.06 & 1.00 & & \\
\hline French & & & -0.19 & -0.08 & -0.17 & -0.12 & -0.39 & -0.17 & -0.15 & 1.00 & \\
\hline Socialist & & & -0.17 & -0.03 & -0.47 & 0.09 & -0.28 & -0.12 & -0.10 & -0.31 & 1.00 \\
\hline
\end{tabular}

Coefficients greater than 0.25 are significant at 0.00 
Table 4 Regression Results-Legal origin impact on socially responsible investment (SRI index)

\begin{tabular}{|l|l|l|l|l|l|l|}
\hline & \multicolumn{2}{|c|}{ Model 1 } & \multicolumn{2}{c|}{ Model 2 } & \multicolumn{2}{c|}{ Model 3 } \\
\hline & $\beta$ & $\mathrm{t}$ & $\beta$ & $\mathrm{t}$ & $\beta$ & $\mathrm{t}$ \\
\hline Log Corruption control & 0.890 & $3.229^{* *}$ & 0.544 & $3.151^{* *}$ & & \\
\hline English legal system & 0.587 & $3.726^{* * *}$ & 0.280 & $0.111^{*}$ & 0.337 & $3.005^{* *}$ \\
\hline German legal system & 1.404 & $5.036^{* * *}$ & 0.915 & $4.654^{* * *}$ & 0.926 & $4.641^{* * *}$ \\
\hline Scandinavian legal system & 1.447 & $4.514^{* * *}$ & 0.985 & $4.381^{* * *}$ & 0.988 & $4.338^{* * *}$ \\
\hline Socialist legal system & -0.139 & -0.779 & -0.0718 & -0.587 & -0.064 & -0.552 \\
\hline Log GDP per capita & 0.490 & $2.948^{* *}$ & & & 0.287 & $2.719^{* *}$ \\
\hline Log GDP $*$ high & & & 0.285 & $11.182^{* * *}$ & & \\
\hline Log Corruption C high & & & & & 0.666 & $11.161^{* * *}$ \\
\hline Constant & -3.765 & $-6.843^{* * *}$ & -1.669 & $-6.094^{* * *}$ & -1.926 & $-4.755^{* * *}$ \\
\hline F statistic & & $25.18^{* * *}$ & & $70.69^{* * *}$ & & $69.1 * * *$ \\
\hline $\mathrm{R}^{2}$ & & 0.609 & & 0.813 & & 0.810 \\
\hline Adj $\mathrm{R}^{2}$ & & 0.584 & & 0.802 & & 0.798 \\
\hline Durbin-Watson & & 1.856 & & 1.916 & & 2.049 \\
\hline
\end{tabular}

$* \mathrm{p}<0.1 ; * * \mathrm{p}<0.05 ; \mathrm{p} * * *<0.01$ 
Table 5 Regression Results-Legal origin impact on voluntary charitable giving (Giving index)

\begin{tabular}{|c|c|c|c|c|c|c|}
\hline & \multicolumn{2}{|l|}{ Model 4} & \multicolumn{2}{|l|}{ Model 5} & \multicolumn{2}{|l|}{ Model 6} \\
\hline & $\beta$ & $\mathrm{t}$ & $\beta$ & $\mathrm{t}$ & $\beta$ & $\mathrm{t}$ \\
\hline Log Corruption control & -2.166 & -0.583 & 2.428 & 0.685 & & \\
\hline English legal system & 8.992 & $4.2 * * *$ & 6.681 & $2.91 * *$ & 7.949 & $3.62 * * *$ \\
\hline German legal system & 3.139 & 0.835 & 3.279 & 0.811 & 1.623 & 0.422 \\
\hline Scandinavian legal system & 5.369 & 1.242 & 5.202 & 1.126 & 3.577 & 0.815 \\
\hline Socialist legal system & -11.493 & $-4.322 * * *$ & -10.610 & $-4.226 * * *$ & -11.527 & $-4.824 * * *$ \\
\hline Log GDP per capita & 9.228 & $4.071 * * *$ & & & 7.198 & $3.448 * * *$ \\
\hline Log GDP * high & & & 1.392 & $2.629 * *$ & & \\
\hline Log Corruption $\mathrm{C}$ *high & & & & & 1.605 & 1.360 \\
\hline Constant & 2.099 & -0.279 & 24.945 & $4.427 * * *$ & 1.505 & 0.188 \\
\hline F statistic & & $13.94 * * *$ & & $11.37 * * *$ & & $14.42 * * *$ \\
\hline $\mathrm{R}^{2}$ & & 0.468 & & 0.417 & & 0.476 \\
\hline $\operatorname{Adj} R^{2}$ & & 0.434 & & 0.381 & & 0.443 \\
\hline Durbin-Watson & & 2.434 & & 2.266 & & 2.363 \\
\hline
\end{tabular}

$* \mathrm{p}<0.1 ; * * \mathrm{p}<0.05 ; \mathrm{p} * * *<0.01$ 


\section{References}

Abbott, W. and Monsen, R.J. (1979) 'On the Measurement of Corporat Social Responsibility: Self-Repored Disclosure as a Method of Measuring Corporatr Social Involvement', Academy of Management Journal, 22 (3), 501-515.

Aguilera, R. and Jackson, G. (2010) 'The cross-national diversity of corporate governance: dimensions and determinants', Academy of Management Annals, 4, 1, 485556.

Aguilera, R., Williams, C., Conley, J., and Rupp, D. (2006). 'Corporate Governance and Corporate Social Responsibility. A Comparative Analysis of the U.K. and the U.S.' . Corporate Governance: An International Review, 14(3): 147-57.

Alas R. and Tafel, K. (2008) 'Conceptualizing the Dynamics of Social Responsibility: Evidence from a Case Study of Estonia' Journal of Business Ethics 81, 371-385.

Amable, B. (2003) The Diversity of Modern Capitalism, Oxford: Oxford University Press.

Armour, J., Deakin, S., Lele, P. and Siems, M. (2009a) 'How do legal rules evolve? Evidence from a cross-country comparison of shareholder, creditor and worker protection', American Journal of Comparative Law, 57, 579-630.

Armour, J., Deakin, S., Sarkar, P., Siems, M., and Singh, A. (2009b) 'Shareholder Protection and Stock Market Development: A Test of the Legal Origins Hypothesis', Journal of Empirical Legal Studies, 6, 343-80.

Ault, J., and Spicer, A (2014) The institutional context of poverty: State fragility as a predictor of cross national variation in commercial microfinance lending, Strategic Management Journal, 35, 1818-1838.

Baughn, C.C., Bodie, N.L., and McIntosh, J. (2007)'Corporate social and environmental responsibility in Asian countries and other geographical regions',Corporate Social Responsibility and Environmental Management, 14, 189-205.

Bengtsson, E. (2008), 'Socially responsible investing in Scandinavia - a comparative analysis', Sustainable Development, 16 (3), 155-168.

Black, B.S, and Tarassova, A.S. (2003) 'Institutional reform in transition: A case study of Russia', Supreme Court Economic Review, 10, 211-278.

Botero, J., S. Djankov, R. La Porta, F. Lopez-de-Silanes, and A. Shleifer (2004). 'The Regulation of Labor', Quarterly Journal of Economics 119: 1339-1382. 
Boyer, R. (2006) 'How do Institutions Cohere and Change'. In Wood, G. and James, P. (eds.), Institutions and Working Life, Oxford: Oxford University Press.

Brammer, S., Jackson, G., and Matten, D. (2012) 'Corporate social responsibility and institutional theory: New perspectives on private governance', Socio-Economic Review 10 (1), 3-28.

Brammer, S., Pavelin, S. and Porter, L. (2008) 'Corporate charitable giving, multinational companies and countries of concern', Working Paper 061, Henley Business School, University of Reading (http://www.reading.ac.uk/web/FILES/management/061.pdf).

Brown, J.A. and Forster, W.R. (2013) 'CSR and Stakeholder Theory: A Tale of Adam Smith', Journal of Business Ethics, 112, 301-312.

Burnell, P., and Ware, A. (Eds.) (2007) Funding Democratization, New Jersey:

Transaction Publishers.

CAF (2010) The World Giving Index

(http://www.cafonline.org/Default.aspx?page $=19428$ )

Central Intelligence Agency, World Factbook

(https://www.cia.gov/library/publications/the-world-factbook/)

Campbell, J.L. (2006) 'Institutional analysis and the paradox of corporate social responsibility', American Behavioral Scientist, 49 (7) 925-938.

Campbell, J. L. (2007) 'Why Would Corporations Behave in Socially Responsible Ways? An Institutional Theory of Corporate Social Responsibility', Academy of Management Review, 32, 946-967.

Carroll A. B., (1991), 'The Pyramid of Corporate Social Responsibility: Toward the Moral Management of Organizational Stakeholders', Business Horizons, 43(4): 39-48.

Chan, C.M., Isobe, T., and Makino, S. (2008) Which country matters? Institutional development and foreign affiliate performance, Strategic Management Journal, 29, 11791205 .

Chen A. (2009) 'Corporate Governance in Russia and some points of comparison with China', The Chinese economy, 42 (3), 41-59

Cornel University Legal Information Institute (https://www.law.cornell.edu/wex/legal_systems)

De Castro, J.O., Meyer, G.D., Strong, K.C., and Uhlenbruck, N. (1996) 'Government objectives and organisational characteristics: A stakeholder view of privatisation effectiveness', International Journal of Organisational Analysis, 4 (4), 373-392. 
Demirbag M, Glaister KW (2010) "Factors determining offshore location choice for R\&D projects: a comparative study of developed and emerging regions". Journal of Management Studies 47(8), 1534-1560.

Demirbag, M., Frecknall-Hughes, J., Glaister, K., and Tatoglu, E. (2013) 'Ethics and taxation: A cross-national comparison of UK and Turkish firms'. International Business Review, 22 (11):100-111.

Demirbag, M., McGuinness, M., Wood, G., and Bayyurt, N. (2015) 'Context, law and reinvestment decisions: Why the transitional periphery differs from other post-state socialist economies'. International Business Review, 24 (6), 955-965.

Demirgüc-Kunt A, Klapper LF and Panos GA (2011) 'Entrepreneurship in post-conflict transition'. Economics of Transition 19(1), 27-78.

DiMaggio, P. J., and Powell, W. W. (1983) 'The iron cage revisited: Institutional isomorphism and collective rationality in organizational fields', American Sociological Review, 48(2), 147-160.

Dore, R. (2000) Stock Market Capitalism: Welfare Capitalism, Cambridge: Cambridge University Press.

Fogel, K. (2006) 'Oligarchic family control: Social economic outcomes and the quality of government', Journal of International Business Studies, 37, 603-622.

Friedman, M. (1997) 'The Social Responsibility of Business is to Increase its Profits', Beauchamp, T. and Bowie, N.(eds), Ethical Theory and Business, Upper Saddle River (N.J.): Prentice Hall.

Gjølberg, M. (2009) 'The origin of corporate social responsibility: global forces or national legacies?' Socio-Economic Review, 4, 605-637.

Godfrey, P.C. (2005) 'The Relationship between Corporate Social Responsibility and Shareholder Wealth: A Risk management Perspective', The Academy of Management Review, 30, 4, 777-798.

Goergen, M., Brewster, C. and Wood, G. (2009) 'Corporate Governance: Non-Equity Stakeholders', Baker, K. and Anderson, R. (eds.), Corporate Governance - Robert W Kolb Series in Finance, New Jersey: John Wiley.

Gourevitch, P. and Shinn, J. (2006) Political Power and Corporate Control: The New Politics of Corporate Governance. Princeton: Princeton University Press.

Habermas, M. (1976) Legitimation Crises. London: Heinemann.

Hair, J.F., Black, W.C., Babin, B.J., Anderson, R.E., and Tatham, R.L. (2006) Multivariate Data Analysis - 6th Ed., Upper Saddle River, New Jersey, Pearson. 
Hall, P. and Soskice, D. (2001) 'An Introduction to the Varieties of Capitalism'. In Hall, P. and Soskice, D. (eds.), Varieties of Capitalism: The Institutional Basis of Competitive Advantage, Oxford: Oxford University Press.

Havrylyshyn, O. (2006). Divergent paths in post-communist transformation: Capitalism for all or capitalism for the few? Basingstoke: Palgrave Macmillan.

Hearit, K. (1995) "“Mistakes were made": Organizations, apologia, and crises of social legitimacy', Communication Studies, 46, 1-17.

Hill, R.P., Ainscough, T., Shank, T. and Manullang, D. (2007) 'Corporate Social Responsibility and Socially Responsible Investing: A Global Perspective', Journal of Business Ethics, 70, 165-174.

Hopkins, M. (2005) 'Measures of Corporate Social Responsibility', International Journal of Management and Decision Making, 6, 3-4, 213 - 231.

Hotho, J. J., and Pedersen, T. (2012) 'Beyond the 'rules of the game': Three institutional approaches and how they matter for international business'. In G. Wood and M.

Demirbag (eds.), Handbook of institutional approaches to international business.

Cheltenham: Edward Elgar Publishing.

Ioannou, I. and Serafeim, G. (2014) 'The Impact of Corporate Social Responsibility on Investment Recommendations', Harvard Business School Working Paper 11-017, 1-45.

Jackson G. and Apostolakou A. (2010) 'Corporate Social Responsibility in Western Europe: An Institutional Mirror or Substitute?', Journal of Business Ethics, 9, 371-394.

Jamali, D. and Mirshak, R. (2007), 'Corporate Social Responsibility (CSR): Theory and Practice in a Developing Country Context', Journal of Business Ethics, 72, 243-262.

Jamali, D., Sidani, Y. and El-Asmar, K. (2009), 'A Three Country Comparative Analysis of Managerial CRS Perspectives: Insights from Lebanon, Syria and Jordan', Journal of Business Ethics, 85, 173-192.

Jawahar, I. M. and McLaughlin, G.L. (2001), 'Toward a Descriptive Stakeholder Theory: An Organizational Life Cycle Approach', The Academy of Management Review 26, 3 , 397-414.

Kiessling, T., Isaksson, L. and Yasar, B. (2015), 'Market Orientation and CSR:

Performance Implications', Journal of Business Ethics, Forthcoming.

Klassen, R. and McLaughlin, C. (1996) 'The Impact of Enviromental Management on Firm Performance', Management Science, 42, 8, 1199-1214. 
Knack, S and Keefer, P. (1995) 'Institutions and economic performance: Cross-country tests using alernative institutional measures, Economics and Politics, 7 (3): 207-227.

Kovaliov R. and Streimikiene D. (2008), 'The Role of Public Sector in Corporate Social Responsability Development in Lithuania', Economics and Management, 13, 557-562.

Krumsick, B. (2003), 'Socially Responsible High Tech Companies: Emerging Issues', Journal of Business Ethics 43, 179-187.

Kuznetsov A., Kuznetsova O. and Warren R. (2009) 'CSR and the legitimacy of business in transition economies: The case of Russia', Scandinavian Journal of Management, 25, $37-45$.

Lane, D. and Myant, M. (2006). 'Introduction'. In Lane, D. and Myant, M. (Eds.), Varieties of Capitalism in Post-Communist Countries, London: Palgrave.

Lane, C., and Wood, G. (2009) 'Capitalist diversity and diversity within capitalism', Economy and Society, 38 (4), 531-551.

Lancee, B., and Van de Werfhorst, H.G. (2012) 'Income inequality and participation: A comparison of 24 countries', Social Science Research, 41 (5):166-178.

La Porta, R., Lopez-de-Silanes, F., Shleifer, A. and Vishny, R. (1998) 'Law and finance', Journal of Political Economy, 106, 1113-1155.

La Porta, R., Lopez-de-Silanes, F., Shleifer, A. and Vishny, R. (2000) 'Investor protection and corporate governance', Journal of Financial Economics, 58, 3-27.

La Porta, R., Lopez-de-Silanes, F. and Shleifer, A. (2008) The Economic Consequences of Legal Origins. Journal of Economic Literature, 46, 2, 285-332.

Luo, Y. (2006) 'Political behavior, social responsibility and perceived corruption: A structuration perspective', Journal of International Business Studies, 37, 747-766.

Lynes, J. and Andrachuk, M. (2008) 'Motivations for corporate social and environmental responsibility: A case study of Scandinavian Airlines', Journal of International Management, 14, 4: 377-390.

Makhmadshoev, D., Ibeh, K. and Crone, M. (2015) 'Institutional influences on SME exporters under divergent transition paths: Comparative insights from Tajikistan and Kyrgyzstan', International Business Review, 24, 6, 1025-1036.

Makkinen, J., and Kourula, A., (2012) Pluralism in political corporate social responsibility, Business Ethics Quarterly, 22, 4, 649-678. 
Marquez, A. and Fombrun, C. (2005) 'Measuring Corporate Social Responsibility', Corporate Reputation Review, 7, 4, 304-308.

Matten, D., \& Moon, J. (2008) 'Implicit' and 'Explicit' CSR: A conceptual framework for a comparative understanding of corporate social responsibility', Academy of Management Review, 33, 2, 404-424.

Mccarthy D. J. and Puffer S. M. (2008) 'Corporate governance as a foundation for corporate social responsibility in transition economies: the Russian experience, Thunderbird International Business Review, 50, 4, 231-243.

Mellahi, K. and Wood, G. (2004a) 'Variances in Social Partnership: Towards a Sustainable Model?', International Journal of Social Economics, 31, 7, 667-683.

Mellahi, K. and Wood, G. (2004b) 'Trade Unions and Social Partnerships'. In Wood, G. and Harcourt, M.(Eds.), Trade Unions and Democracy, Manchester: Manchester University Press.

Mellahi, K., Demirbag, M. and Wood, G. (2012), "Regulatory Context and Corruption: Rethinking the Effects of Government Intervention", International Studies of Management and Organization,42,3,13-34.

Mellahi, K., Morrell, K. and Wood, G. (2010) The Ethical Business, London: Palgrave.

Mitchell, N. (1989) The Generous Corporation: A Political Analysis of Economic Power, New Haven: Yale.

Mizobata, S. (2010) 'Divergent path of Corporate Social Responsibility: Russian case and comparative perspective', Paper for EACES 2010, Session IV of Social Changes and Institutions Conference - Through the lens of CSR and market, Tartu, Estonia.

Munoz-Torres, M. J., Fernandez-Izquierdo, M.A. and Balaguer-Franch, M.R. (2004), 'The Social Responsibility Performance of Ethical and Solidarity Funds: An Approach to the Case of Spain', Business Ethics: A European Review, 13, 2-3, 200-218.

Mygind, N., Demina, N., Gregoric, A. and Kapelyusnikov, R. (2006), 'Corporate Governance During Transition: A Comparison of Russia and Slovenia', Corporate Ownership and Control, 3, 4, 52-64.

North, D (1990) Institutions, Institutional Change and Economic Performance, Cambridge: Cambridge University Press.

Oberman, W. (2000) 'Review: The Conspicuous Corporation: Business, Public Policy, and Representive Democracy', Business and Society, 39, 2, 239-244. 
O'Hagan. E. (2002) Employee Relations in the Periphery of Europe, Basingstoke:

Palgrave Macmillan.

Peters, G. (2005) Institutional Theory in Political Science: The New Institutionalism, London: Continuum.

Polishchuk L. (2009), Corporate Social Responsibility vs. Government Regulation: Institutional Analysis with an Application to Russia, IRIS centre.

Porter, M., Schwab, K., Sala-i-Martin, X., López-Claros, A. (Eds.) (2004) The Global Competitiveness Report 2004-2005: Palgrave-McMillan.

Porter, M.E., Schwab, K., and Lopez-Claros, A. (Eds.) (2005) The Global Competitiveness Report 2005-2006: Policies Underpinning Rising Prosperity: PalgraveMcMillan.

Roe, M. (2003) Political Determinants of Corporate Governance, Oxford: Oxford University Press.

Rodriguez, P., Siegel, D.S., Hillman, A., and Eden, L. (2006) 'Three lenses on multinational enterprise: Politics, corruption, and corporate social responsibility', Journal of International Business Studies, 37, 733-746.

Satter, D. (2004) Darkness at Dawn: The Rise of the Russian Criminal State. New Haven: Yale University Press.

Schwartz, M.S. and Carroll, A.B. (2003), 'Corporate Social Responsibility: A threeDomain Approach', Business Ethics Quarterly, 13, 4, 503-530.

Scott, W. R. (1995) Institutions and organisations. Thousand Oaks, CA: Sage Publications.

Singer, P. (1995) Practical Ethics, Cambridge: Cambridge University Press.

Sparkes, R. and Cowton, C. (2004), 'The Maturing of Socially Responsible Investment: A Review of the Developing Link with Corporate Social Responsibility', Journal of Business Ethics, 52 (1), 45-57.

Streeck, W. (2009) Reforming Capitalism: Institutional Change in the German Political Economy. Oxford: Oxford University Press.

Tatoglu, E., Bayraktar, E., Sahadev, S., Demirbag, M., and Glaister, K. (2014)

Determinants of voluntary environmental management practices by MNE subsidiaries, Journal of World Business, 49 (4), 536-548. 
Thelen, K. (1999) 'Historical Institutionalism in Comparative Politics', Annual Review of Political Science, 2, 369-404.

Turker, D. (2008) 'Measuring Corporate Social Responsibility: A Scale Development Study', Journal of Business Ethics, 85 (4) 411-427.

Übius Ü. and Alas R. (2010) 'The innovation climate - predictor for Corporate Social Responsibility (CSR)', Estonian Business School (EBS) Review, 27, 70-86.

Van der Vliert, E (2003) Thermoclimate, culture and poverty and country level roots of workers' wages, Journal of International Business Studies, 34, 40-52.

Whitley, R. (1999) Divergent Capitalisms. Oxford: Oxford University Press.

Williamson, O. (2000). 'The new institutional economics: Taking stock, looking ahead', Journal of Economic Literature, 38(3), 595-613.

Wood, G. and Frynas, J.G. (2006). 'The Institutional basis of economic failure: anatomy of the segmented business system', Socio-Economic Review, 4(2), 239-277.

Wood, G., Dibben, P. and Ogden, S. (2014). "Comparative capitalism without capitalism, and production without workers: The limits and possibilities of contemporary institutional analysis", International Journal of Management Reviews, 16 (4): 384-396.

Wood, G., and Demirbag (2012). Handbook of Institutional Approaches to International Business, Cheltenham: Edward Elgar.

Wood, G., and Demirbag, M. (2015). Business and society on the transitional periphery: Comparative perspectives, International Business Review, 24 (6), 917920.

World Bank (2010), The Worldwide Governance Indicators (WGI) project, (http://info.worldbank.org/governance/wgi/index.asp)

\section{Endnotes}

\footnotetext{
${ }^{\mathrm{i}}$ However, Business systems theory does also cover the developed Far Eastern economies, and has recently been applied to Africa (Wood and Frynas 2006)
} 